\title{
A comparative study of the gelation properties of whey protein concentrate and whey protein isolate
}

\author{
Peter Christian LORENZEN*, Katrin SCHRADER \\ Federal Research Centre for Nutrition and Food, Institute of Dairy Chemistry and Technology, \\ PO Box 6069, 24121 Kiel, Germany
}

Received 30 August 2005 - Accepted 3 April 2006

\begin{abstract}
The present paper describes a comparative study of the gelation properties of whey protein concentrate (WPC) and whey protein isolate (WPI). Penetration measurements as well as rheological studies revealed that the strength of heat-induced gels prepared with WPI was higher than with WPC. In addition, gels with WPI were clearly more elastic than WPC gels. The storage modulus of WPI and the storage and loss moduli of WPC increased with increasing frequency, while the loss modulus of WPI revealed no clear dependence on the frequency, resulting in a greater decrease in the loss angle of WPI with increasing frequency. The superior gelation properties of WPI were mainly due to the higher $\beta$-lactoglobulin content as well as to lower fat, lactose and phospholipid contents. However, in this paper it is also discussed whether the low contents of glycomacropeptide, non-protein-nitrogen and proteose peptone in WPI may partly explain the superior gelation properties of these protein products. WPI were more sensible to an increase in the ionic strength $(0.1-0.3 \%$ $\mathrm{NaCl}$ ) than WPC, resulting in clearly stronger gels with WPI than with WPC. In the $\mathrm{pH}$ ranges of 2-3 and 7-8, elastic and translucent gels could be prepared using WPI, while their gel-forming properties were low between $\mathrm{pH} 4$ and 5 . The strongest gels, turbid, but still elastic, were prepared with WPI at $\mathrm{pH} 6$.
\end{abstract}

whey protein concentrate / whey protein isolate / gelation properties

摘要 - 乳清浓缩蛋白和乳清分离蛋白凝胶特性的对比研究。本文对乳清浓缩蛋白 (WPC) 和 乳清分离蛋白 (WPI) 的凝胶特性进行了对比研究。根据穿透试验的研究表明热处理后 WPI 的凝胶强度明显高于 WPC。此外, WPI 凝胶的弹性明显优于 WPC 凝胶。WPI 的储能模量 和 WPC 的储能及损耗模量随着频率的增加而增加, 而 WPI 的损耗模量则是随着频率的增 加而急剧下降。WPI 优良的凝胶特性主要原因是其 $\beta$ - 乳球蛋白的含量较高, 而脂肪、乳 糖和磷脂含量低, 还有可能是存在于 WPI 中低含量的酪蛋白糖聚肽、非蛋白氮和蛋白胨赋 予了其优良的凝胶特性。在 $0.1 \% \sim 0.3 \% \mathrm{NaCl}$ 溶液中 WPI 的凝胶强度随着离子强度的增加 而提高, 因而 WPI 的凝胶强度明显高于 WPC。WPI 在 $\mathrm{pH} 2 \sim 3$ 和 $\mathrm{pH} 78$ 时可以制备弹 性好和半透明状的凝胶，而在 $\mathrm{pH} 4 \sim 5$ 时制成凝胶的性能较差。WPI 在 $\mathrm{pH} 6$ 时制备的凝胶 强度最大, 凝胶呈浑浊状但仍具有弹性。

乳清浓缩蛋白 / 乳清分离蛋白 / 凝胶特性

\footnotetext{
* Corresponding author (通讯作者): peter-christian.lorenzen@bfel.de
} 
Résumé - Présentation d'une étude comparative sur les propriétés de gélification du concentré protéique de lactosérum WPC et de l'isolat protéique de lactosérum WPI. Des mesures de la pénétration ainsi que des études rhéologiques révèlent que la solidité des gels obtenus par gélification thermique est plus élevée en utilisant WPI que WPC. De plus, les gels avec WPI sont nettement plus élastiques que des gels avec WPC. Le module de stockage de WPI et les modules de stockage et de perte de WPC augmentaient avec une fréquence croissante, tandis que les modules de perte de WPI n'étaient pas influencés par la fréquence, et menaient ainsi à une forte réduction de l'angle de perte de WPI avec une fréquence croissante. Les propriétés supérieures de gélification de WPI sont principalement dues à une teneur élevée en $\beta$-lactoglobuline et à une teneur réduite en matière grasse, lactose et phospholipide. Dans l'étude présente, il est également discuté si les faibles teneurs en glycomacropeptide, en azote non-protéique de WPI et en protéose peptone dans WPI expliquent partiellement les propriétés supérieures de gélification de ces produits protéiques. WPI réagissait plus sensiblement à une augmentation de la teneur ionique $(0.1-0.3 \% \mathrm{NaCl})$ que $\mathrm{WPC}$, aboutissant à des gels ostensiblement plus solides avec WPI qu'avec WPC. Avec un pH entre 2-3 et $7-8$, il a été possible de préparer des gels élastiques et translucides en utilisant WPI, tandis que les propriétés gélifiantes étaient faibles avec un $\mathrm{pH}$ entre 4-5. Les gels les plus solides, d'un aspect trouble mais encore élastiques, étaient préparés avec WPI à un $\mathrm{pH} 6$.

concentré protéique de lactosérum / isolat protéique de lactosérum / propriété de gélification

\section{INTRODUCTION}

The consistency of foods, often characterized by the water-holding and/or fat crystallization properties of the ingredients, is of particular importance in food processing. The gelling ability of proteins provides important textural and water-holding properties in many foods. In particular, gelatine, the only protein among the hydrocolloids, is used as a gelling agent. Apart from gelatine, other food proteins, such as whey proteins, possess gelation properties $[13,31$, 41].

The mechanisms of heat-induced gelation of whey proteins are not yet completely understood. Former investigations interpreted the gelation as a two-phase process consisting of unfolding of the globular structure, and subsequent aggregation of protein chains into a three-dimensional network. Today, gelation of whey proteins is basically considered as a four-phase process [36] consisting of unfolding of the native structure (I), aggregation of the unfolded protein molecules (II), string formation of the aggregates (III), and linkage of the strings to a three-dimensional network (IV). Partially stable intermediates of the three-dimensional structure of whey proteins, called the "molten globule state", are of particular importance during gelation $[16,31]$. The formation of heat-induced whey protein gels, mainly due to disulfide bridges and hydrophobic interactions, is irreversible $[9,10,36]$. The structure and consistency of the gels depend on protein concentration, ion strength and type as well as on $\mathrm{pH}$ value, temperature and degree of denaturation [7-10, 17, 36]. Furthermore, the origin of the whey (rennet casein, cheese or acid casein production) as well as the operations used for concentrating, isolating and/or fractionating proteins are particularly relevant for the resulting properties of the whey protein products $[27,36]$. Cold set whey protein gels can be prepared by heating the proteins at neutral $\mathrm{pH}$ and low ionic strength, keeping the substrate concentration below the concentration which is required to create a network. The gelation itself is induced by adding salt (transparent gels) or acid (turbid gels) to the heat-treated protein solutions after cooling $[1,4,33,38]$. An enzyme-induced gelation of whey proteins can be obtained by partial hydrolysis with an endopeptidase from Bacillus licheniformis [29]. A pressure-induced gelation of milk proteins can be obtained by applying high hydrostatic pressure [26].

A number of papers are concerned with the mechanisms of whey protein gelation e.g. $[6,9,10,14,17,34,39]$. Comparative studies on the compositional, physicochemical and functional properties of whey protein concentrate (WPC) and whey protein isolate (WPI) are also described in the 
literature e.g. $[3,5,11,12,20,21,27]$. The present paper, however, represents a comparative study of the gelation properties of WPC and WPI prepared from the same source of whey.

\section{MATERIALS AND METHODS}

\subsection{Materials}

Several batches of WPC and WPI were purchased from Milei GmbH, Stuttgart, Germany. The whey protein products were prepared from pasteurized, sweet whey by ultrafiltration (WPC) or ion-exchange chromatography (WPI) with subsequent ultrafiltration followed by spray-drying $\left(180^{\circ} \mathrm{C}\right.$ inlet/80 ${ }^{\circ} \mathrm{C}$ outlet).

\subsection{Characterization of functional and chemical properties}

\subsubsection{Penetration measurement}

In order to characterize the heat-induced gelation of the proteins, solutions with a protein content of $11.25 \%$ in demineralized water were prepared and heated in a water bath at $75^{\circ} \mathrm{C}$ for $45 \mathrm{~min}$. Subsequently, the gels were stored for $90 \mathrm{~min}$ in the refrigerator $\left(4-6{ }^{\circ} \mathrm{C}\right)$. The characterization of the gel strength was determined at $10^{\circ} \mathrm{C}$ by penetration measurements (Stevens-L.F.R.A. Texture Analyser, CNS Farnell, Borehamwood, UK). The instrument was adjusted to the following conditions: cylindrical probe, probe area $1 \mathrm{~cm}^{2}$, penetration distance: $20 \mathrm{~mm}$ into surface, penetration speed: $1.0 \mathrm{~mm} \cdot \mathrm{s}^{-1}$. Gel strength was determined in triplicate and expressed as $\mathrm{N} \cdot \mathrm{cm}^{-2}$ of probe area. The standard deviation in these studies was between 0.02 and 0.7 .

\subsubsection{Determination of sialic acid}

Sialic acid was determined according to annex IV of EU regulation (EG) 625/78 [2]. Trichloroacetic acid (TCA) was added to solutions of the whey proteins in demineralized water ( WPC 4.66\%, WPI 3.88\%) up to $12 \%$. After TCA treatment, caseinmacropeptides - which contain sialic acid - were precipitated from the supernatant by addition of phosphorus tungstic acid. Sialic acid, liberated by acid hydrolysis, was detected after complex formation with resorcin by a spectrophotometric measurement at $\lambda=580 \mathrm{~nm}$. Determinations were performed in triplicate.

\subsubsection{Degree of denaturation}

Solutions of the protein products in demineralized water (protein content about $2.5 \%$ ) were adjusted to $\mathrm{pH} 4.6$ by addition of acidic acid and stored for $24 \mathrm{~h}$ at room temperature. After this, samples for determination of the protein content were taken (value A). The remaining dispersions were filtered (S\&S 1574) and the protein content of the filtrates (value B) was also examined. The degree of denaturation (D) was calculated according to the formula: $\mathrm{D}(\%)=\mathrm{A}-\mathrm{B}$ divided by $A \times 100$. Determinations were performed in triplicate.

\subsubsection{Characterization of the molecular weight distribution by size-exclusion chromatography}

Size-exclusion chromatography was performed using a FPLC 2000 System (Pharmacia, Sweden) with a Superdex 200 HR10/30-Column (buffer: 0.1 $\mathrm{mol} \cdot \mathrm{L}^{-1}$ Tris, $0.15 \mathrm{~mol} \cdot \mathrm{L}^{-1} \mathrm{NaCl}, 8 \mathrm{~mol} \cdot \mathrm{L}^{-1}$ Urea, pH 8.0, flow rate: $\left.0.3 \mathrm{~mL} \cdot \mathrm{min}^{-1}\right)$. The buffer was filtered through $0.2-\mu \mathrm{m}$ filters and degassed under vacuum. The samples were diluted with buffer to a final concentration of $2 \mathrm{mg}$ protein $\cdot \mathrm{mL}^{-1}$ buffer. After filtration $(0.2 \mu \mathrm{m}) 25 \mu \mathrm{L}$ were injected and eluted at room temperature. The absorbance of the eluate was monitored at $\lambda=280 \mathrm{~nm}$. Gel filtration calibration kits (LMW/ HMW) from Pharmacia, Sweden were used to characterize the eluted peaks.

\subsubsection{Determination of the rheological properties of whey protein gels}

For characterization of the visco-elastic properties a rheometer UDS 200 (Physica, Ostfildern, Germany) was used. The whey protein gels were produced in the measuring system (MP 31, plate/plate, diameter 
Table I. Strength of gels made with whey protein concentrate and isolate in relation to the conditions of preparation (unless otherwise noted: protein content $=11.25 \%, \mathrm{pH}=7.0$, heating temperature $=75^{\circ} \mathrm{C}$, heating time $=45 \mathrm{~min}$, average of 3 determinations \pm standard deviation).

\begin{tabular}{lccc}
\hline \multicolumn{1}{c}{ Conditions of preparation } & \multicolumn{2}{c}{ Gel strength $\left(\mathrm{N} \cdot \mathrm{cm}^{-2}\right)$} \\
& & $\begin{array}{c}\text { Whey protein } \\
\text { concentrate }\end{array}$ & $\begin{array}{c}\text { Whey protein } \\
\text { isolate }\end{array}$ \\
\hline Heating & $70^{\circ} \mathrm{C}$ & $0.12 \pm 0.02$ & $2.5 \pm 0.5$ \\
& $80^{\circ} \mathrm{C}$ & $0.32 \pm 0.05$ & $6.0 \pm 0.5$ \\
Protein content & $90^{\circ} \mathrm{C}$ & $0.74 \pm 0.05$ & $8.0 \pm 0.6$ \\
& $8 \%$ & $0.53 \pm 0.05$ & $0.05 \pm 0.04$ \\
& $10 \%$ & $1.47 \pm 0.05$ & $1.1 \pm 0.06$ \\
pH value & $12 \%$ & $3.1 \pm 0.4$ & $9.0 \pm 0.7$ \\
& 4.0 & $0.10 \pm 0.04$ & $0.13 \pm 0.02$ \\
Sodium chloride & 6.0 & $0.14 \pm 0.04$ & $5.5 \pm 0.3$ \\
& 8.0 & $1.3 \pm 0.04$ & $0.4 \pm 0.04$ \\
& $0.1 \%$ & $0.39 \pm 0.05$ & $4.6 \pm 0.3$ \\
& $0.2 \%$ & $0.34 \pm 0.05$ & $8.9 \pm 0.5$ \\
& $0.3 \%$ & $0.28 \pm 0.05$ & $10.0 \pm 0.4$ \\
\hline
\end{tabular}

$50 \mathrm{~mm}$, gap $1 \mathrm{~mm}$ ) under the same heating conditions as described under 2.2.1. Immediately after the cooling phase a frequency sweep was recorded at a temperature of $5{ }^{\circ} \mathrm{C}$. A constant deformation of $0.1 \%$ was chosen. The frequency varied from $10 \mathrm{~s}^{-1}$ to $0.1 \mathrm{~s}^{-1}$. The storage modulus $\left(\mathrm{G}^{\prime}=\right.$ elastic part) and loss modulus (G" = viscous part) were measured and the loss angle (proportion between elastic and viscous parts) was calculated. Determinations were performed in quadruplicate.

\subsubsection{Analytical methods}

The composition of the whey protein products as well as SDS-PAGE, non-denaturing PAGE and determination of non-protein-nitrogen were performed by evaluated methods according to the VDLUFA-Methodenbuch, Band 6 (2004). Instead of SDS and DTT in the sample buffer of SDSPAGE, Tris/HCl and mercaptoethanol were used in the sample buffer of the nondenaturing PAGE. The amino acid composition was analyzed according to Meisel and Frister [25].

\section{RESULTS AND DISCUSSION}

The resulting technological-functional properties of whey proteins are influenced by - among other things - the production process applied. In this context, the effect of the operation used on the gelation properties of WPC and WPI were studied. Table I shows the gel strength of whey protein products in relation to the time-temperature conditions of heating, protein content, $\mathrm{pH}$ value and sodium chloride content.

It can be seen from Table I that the strength of gels prepared with WPI is about tenfold higher than those prepared with the protein concentrate. An increase in the gel strength with raising heating temperatures is due to a higher number of protein-protein interactions; above all, of non-covalent hydrophobic interactions. This is also valid for the gelation properties in relation to the protein content $[10,17,36]$. The superior gelation properties of WPI are mainly due to a different composition of the products. In comparison with WPC, the isolates contain only low amounts of fat and phospholipids as well as lactose (Tab. II). Wang and 
Table II. Composition of whey protein concentrate and isolate.

\begin{tabular}{lccc}
\hline & & $\begin{array}{c}\text { Whey protein } \\
\text { concentrate }\end{array}$ & $\begin{array}{c}\text { Whey protein } \\
\text { isolate }\end{array}$ \\
\hline Protein & $(\%)$ & 70.5 & 92.6 \\
Lactose & $"$ & 14.8 & 1.1 \\
Fat & $"$ & 5.2 & traces \\
Moisture & $"$ & 4.9 & 4.1 \\
Ash & $\mathrm{mg} \cdot 100 \mathrm{~g}^{-1}$ product & 3.3 & 1.9 \\
Calcium & $"$ & 570 & 150 \\
Magnesium & $"$ & 85 & 10 \\
Potassium & $"$ & 480 & 1 \\
Sodium & $"$ & 110 & 600 \\
Chloride & $"$ & 420 & 60 \\
Phosphate & & & 40 \\
\hline
\end{tabular}

Table III. Characterizing parameter of whey protein concentrate and isolate (average of 3 determinations \pm standard deviation).

\begin{tabular}{lccc}
\hline & & $\begin{array}{c}\text { Whey protein } \\
\text { concentrate }\end{array}$ & $\begin{array}{c}\text { Whey protein } \\
\text { isolate }\end{array}$ \\
\hline Sialic acid ${ }^{1}$ & $\mu \mathrm{g} \cdot \mathrm{mg}^{-1}$ protein & $6.14 \pm 0.17$ & $0.15 \pm 0.02$ \\
Non-protein-nitrogen & $(\%)$ & $0.72 \pm 0.003$ & $0.03 \pm 0.002$ \\
Ratio of $\beta-\mathrm{Lg}$ to $\alpha-\mathrm{La}^{2}$ & $(\%)$ & $1.4: 1.0$ & $3.4: 1.0$ \\
Ratio of $\beta-\mathrm{Lg}$ to $\alpha-\mathrm{La}^{3}$ & $(\%)$ & $1.8: 1.0$ & $3.2: 1.0$ \\
Degree of denaturation & $(\%)$ & $10.9 \pm 1.8$ & $5.2 \pm 1.2$ \\
\hline
\end{tabular}

${ }^{1}$ Average values in several batches of WPC and WPI.

2 According to size-exclusion chromatography (sum of $\beta$ - $\operatorname{Lg}$ and $\alpha-\operatorname{La}=100 \%$, see Figs. 1 and 2).

3 According to SDS-PAGE (sum of $\beta$-Lg and $\alpha$-La $=100 \%$, see Figs. 3 and 4).

Lucey [40] found that compared with WPI, WPC has similar major proteins, but more large-sized residual lipid material and different minor constituents. For instance, the mineral composition of the protein products is quite different (Tab. II). WPC shows distinctly higher contents of calcium, potassium, phosphate and chloride, while the sodium content is twofold higher in WPI. These differences significantly affect the gelation properties of whey proteins.

The concentration of sialic acid in the whey protein products was determined, because it reflects the amount of glycomacropeptide (GMP) present [28]. From Table III it can be seen that the sialic acid content in
WPC is distinctly higher than in WPI. The same relation was found by Nakano and Ozimek [28], but they found higher values for WPC (15-18 $\left.\mu \mathrm{g} \cdot \mathrm{mg}^{-1}\right)$ and WPI $\left(1.7 \mu \mathrm{g} \cdot \mathrm{mg}^{-1}\right)$. According to Huffman [22], the GMP content in WPC is up to $26 \%$ of the total protein content. Wang and Lucey [40] found that there was very little GMP $(<2 \%)$ in WPI made using an ion-exchange process compared with levels of up to $26 \%$ of the total protein content in WPI made by membrane filtration processes, respectively. The supplier of the whey protein products analyzed the WPC and WPI in relation to the annex IV of EU regulation (EG) $1725 / 79$ (1999), which allows only a 


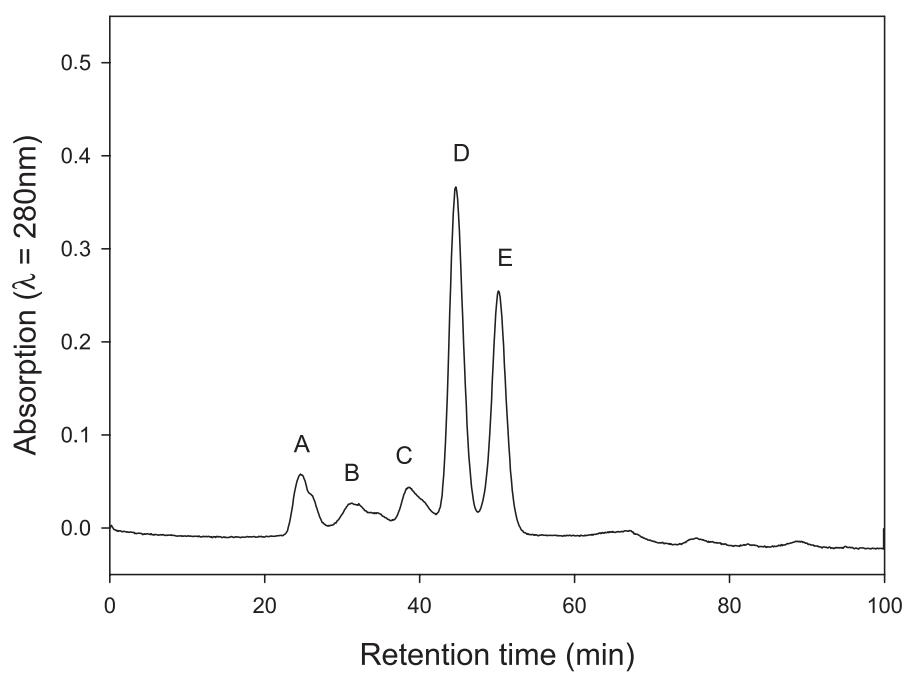

Figure 1. Size-exclusion chromatogram of whey protein concentrate: $\mathrm{A}=0,7-2 \times 10^{6} \mathrm{~g} \cdot \mathrm{mol}^{-1} ; \mathrm{B}=$ $158-232 \times 10^{3} \mathrm{~g} \cdot \mathrm{mol}^{-1} ; \mathrm{C}=60-70 \times 10^{3} \mathrm{~g} \cdot \mathrm{mol}^{-1} ; \mathrm{D}=\beta$-lactoglobulin and $\mathrm{E}=\alpha$-lactalbumin.

relative comparison. They found that the GMP content in WPC corresponds to an amount of $750 \%$ sweet whey powder, while that in WPI is comparable with $1.5 \%$ sweet whey powder. This potentially marked difference in GMP levels decreases the level of $\beta$-lactoglobulin in WPC. It is likely that this reduces the gelation properties of WPC in comparison with WPI. The non-proteinnitrogen (NPN) content of the whey protein products is also different (Tab. III). The present studies show that WPI contains hardly any NPN, while WPC shows an average content of $0.72 \%$. Morr and Foegeding [27] also found that the NPN content is higher in WPC than in WPI. The NPN fraction, which migrates into whey during cheese-making, consists - among other things - of amino acids and peptides [23]. Haque [19] reported that hydrophobic peptides in milk or whey, which will be concentrated by ultrafiltration, may mask hydrophobic areas of proteins. Brandenburger et al. [3] hypothesized that variations in WPC and WPI functionality might be due, in part, to differences in their low-molecular-weight components, i.e. mainly peptides, lactose and minerals. Further, the content of prote- ose peptones (PP) in WPC is also distinctly higher than in WPI [15]. It appears that the PP fraction contains casein and fat globule membrane-derived peptides as well as a number of minor proteins which are indigenous to milk. Especially PP3 has been referred to as the hydrophobic fraction of PP [18]. So, it cannot be excluded that hydrophobic areas of heat-induced, partly unfolded whey proteins in WPC are covered by hydrophobic amino acids, hydrophobic or amphipathic peptides or minor proteins as part of the NPN or PP fraction, making the formation of a regular gel more difficult.

Furthermore, the protein composition of the products is different. While the relation of $\beta$-lactoglobulin to $\alpha$-lactalbumin - analyzed by size-exclusion chromatography (Figs. 1 and 2, Tab. III) and SDS-PAGE (Figs. 3 and 4, Tab. III) - is less than two-toone with the concentrate, it is greater than three-to-one with the isolate. Performing the non-denaturing electrophoresis suggests that the protein isolate contains greater amounts of polymers than the protein concentrate (Fig. 4, Tab. IV). The results of the size-exclusion chromatography 


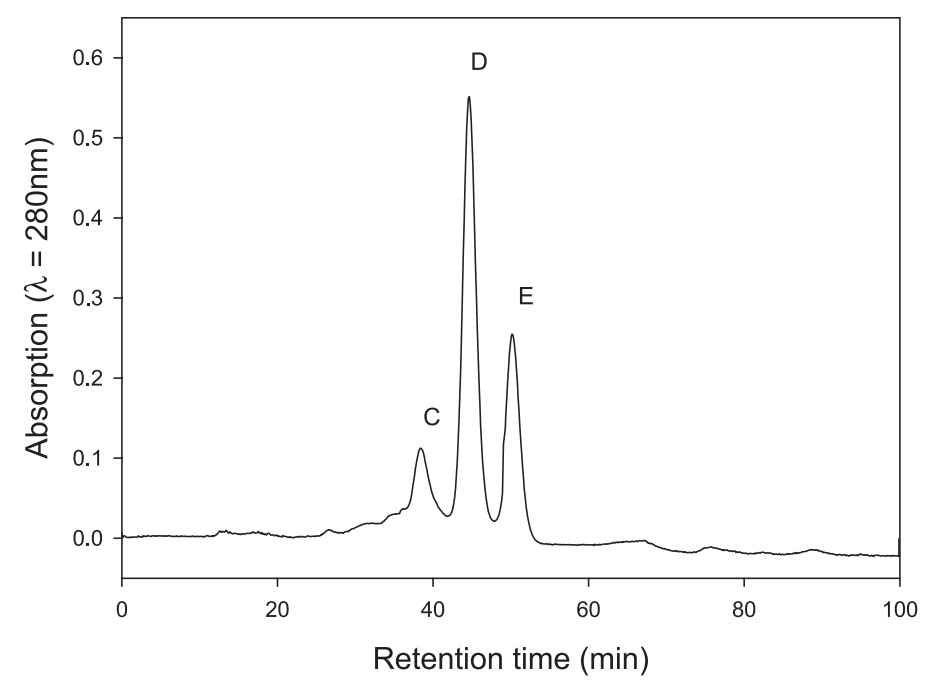

Figure 2. Size-exclusion chromatogram of whey protein isolate: $\mathrm{C}=60-70 \times 10^{3} \mathrm{~g} \cdot \mathrm{mol}^{-1} ; \mathrm{D}=\beta$ lactoglobulin and $\mathrm{E}=\alpha$-lactalbumin.

Table IV. Protein composition of whey protein concentrate and isolate according to SDS- and nondenaturing PAGE (average of 2 runs).

\begin{tabular}{lccccc}
\hline & \multicolumn{2}{c}{$\begin{array}{c}\text { Whey protein } \\
\text { concentrate }\end{array}$} & \multicolumn{2}{c}{$\begin{array}{c}\text { Whey protein } \\
\text { isolate }\end{array}$} \\
\hline & & A & B & A & B \\
$\alpha$-Lactalbumin & $(\%)$ & 35.0 & 28.9 & 23.0 & 23.0 \\
$\beta$-Lactoglobulin & $(\%)$ & 64.3 & 59.8 & 74.1 & 60.2 \\
Bovine serum albumen & $(\%)$ & 0.7 & 3.9 & 2.9 & 5.2 \\
Polymers $\left(1-2 \times 10^{5} \mathrm{~g} \cdot \mathrm{mol}^{-1}\right)$ & $(\%)$ & - & 7.4 & - & 11.6 \\
\hline
\end{tabular}

A = SDS-PAGE (sample buffer contains $0.6 \mathrm{~g}$ SDS and $20 \mathrm{mg}$ DTT per $20 \mathrm{~mL}$ water).

$\mathrm{B}=$ Non-denaturing PAGE (sample buffer contains $4 \mathrm{ml}$ Tris $/ \mathrm{HCl}\left(0.5 \mathrm{~mol} \cdot \mathrm{L}^{-1}, \mathrm{pH} 6.8\right)$ and $1.6 \mathrm{~mL}$ mercaptoethanol per $16 \mathrm{~mL}$ water).

(Figs. 1 and 2), however, reveal that - under the conditions applied (see 2.2.4) - WPC contains polymers, while WPI does not. Wang and Lucey [40] demonstrated by size-exclusion chromatography studies that the polymer peak of the WPC chromatogram contains mainly small lipid globules or phospholipids. The detection of polymers in non-denaturing electrophoresis, on the other hand, may be the result of selfassociation of $\beta$-lactoglobulin under nonreducing conditions [35]. In addition, the degree of denaturation of proteins is important regarding their ability to gel, because only non-denatured whey proteins can form strong gels. From Table III it can be seen that the degree of denaturation of WPC is twice as high as that of WPI.

Furthermore, the influence of $\mathrm{pH}$ on the gelation properties of WPC and WPI was studied. Table I reveals the gel strength of the whey products, while Figures 5 and 6 show pictures of gels prepared with WPC or WPI in relation to varying $\mathrm{pH}$ values. 

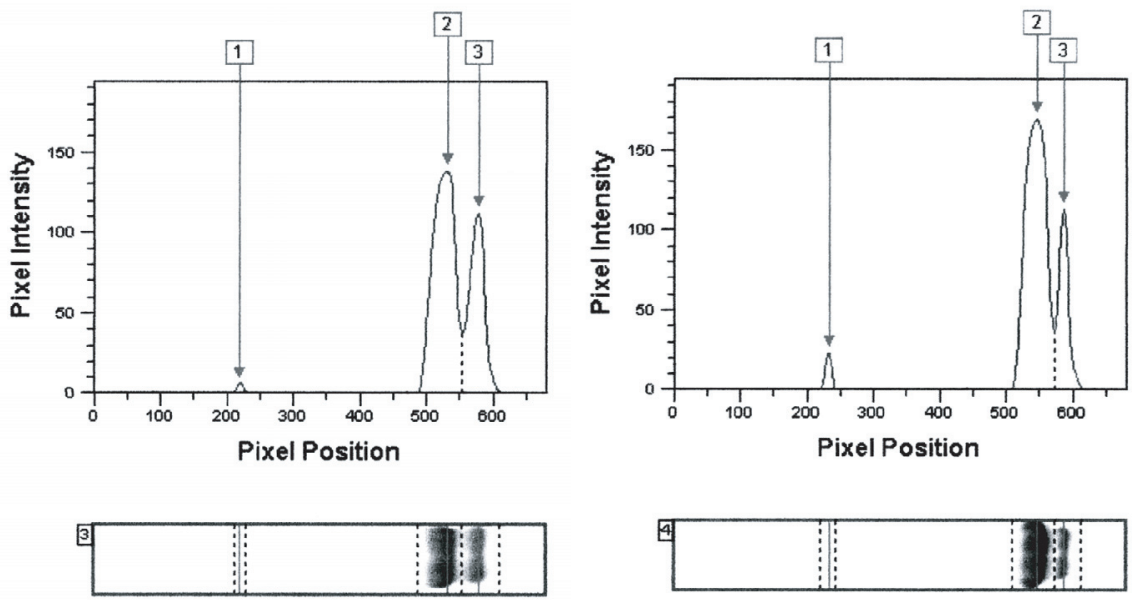

Figure 3. Electropherogram and densitometric analysis of SDS-PAGE of WPC: $1=$ bovine serum albumin, $2=\beta$-lactoglobulin and $3=\alpha$-lactalbumin.
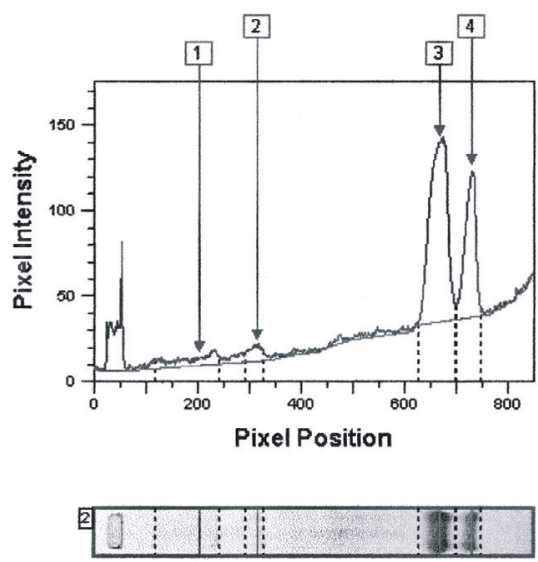

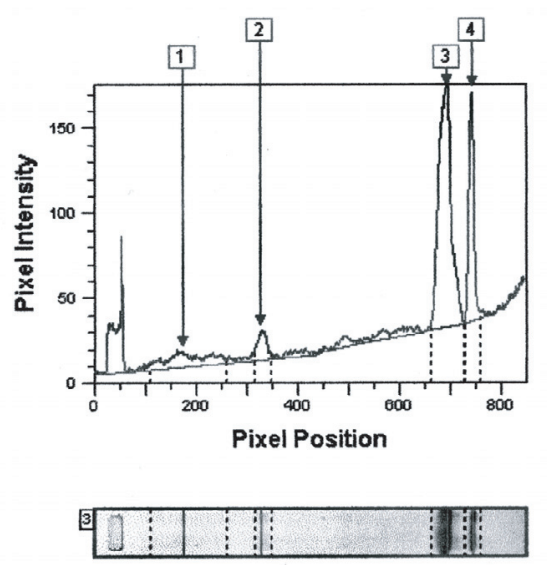

Figure 4. Electropherogram and densitometric analysis of SDS-PAGE of WPI: $1=$ polymers $(1-$ $\left.2 \times 10^{5} \mathrm{~g} \cdot \mathrm{mol}^{-1}\right) ; 2=$ bovine serum albumin; $3=\beta$-lactoglobulin and $4=\alpha$-lactalbumin.

It can be seen that the appearance of the gels in relation to the $\mathrm{pH}$ is comparable, but those prepared from WPI are more translucent at low and high $\mathrm{pH}$ values. This may be due to the presence of fat and phospholipids in WPC.

In principle, whey protein gels at $\mathrm{pH}$ values of 7-8 are mainly stabilized via covalent disulfide bridges. A high net charge avoids the formation of large aggregates. A translucent gel is created from regular thin strings of protein aggregates. At $\mathrm{pH} 6$ noncovalent bonds will be linked, in addition to disulfide bridges, that jointly guarantee high gel strength. The creation of non-covalent bonds leads to the formation of larger aggregates, which results in turbid gels. At $\mathrm{pH}$ values in the iso-electric area of whey 


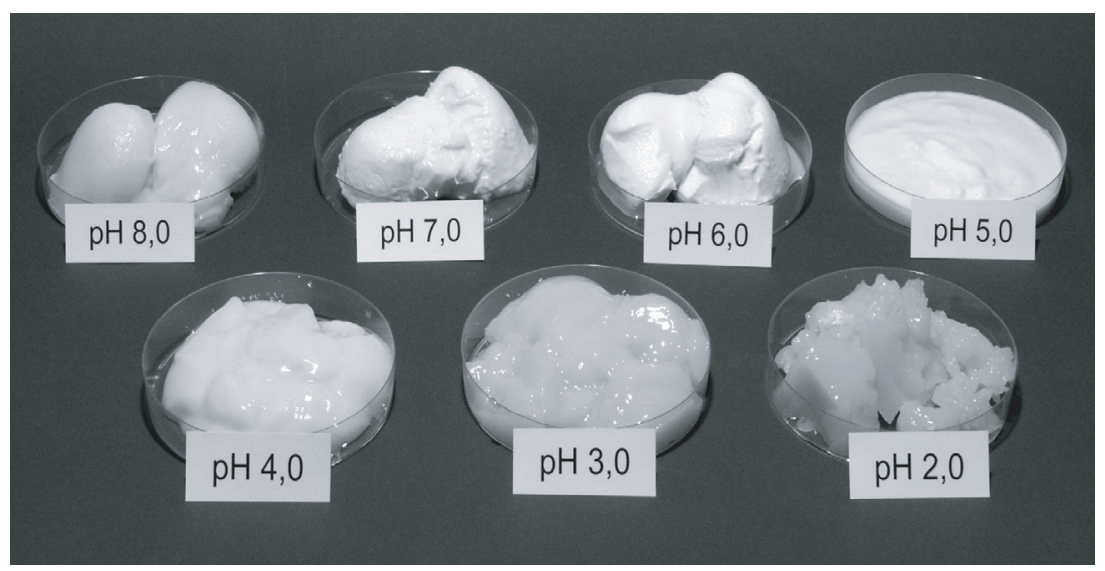

Figure 5. Gelation properties of whey protein concentrate, dependent on the $\mathrm{pH}$ value (protein content $=11.25 \%$; heating conditions $=75^{\circ} \mathrm{C}, 45 \mathrm{~min}$ ).

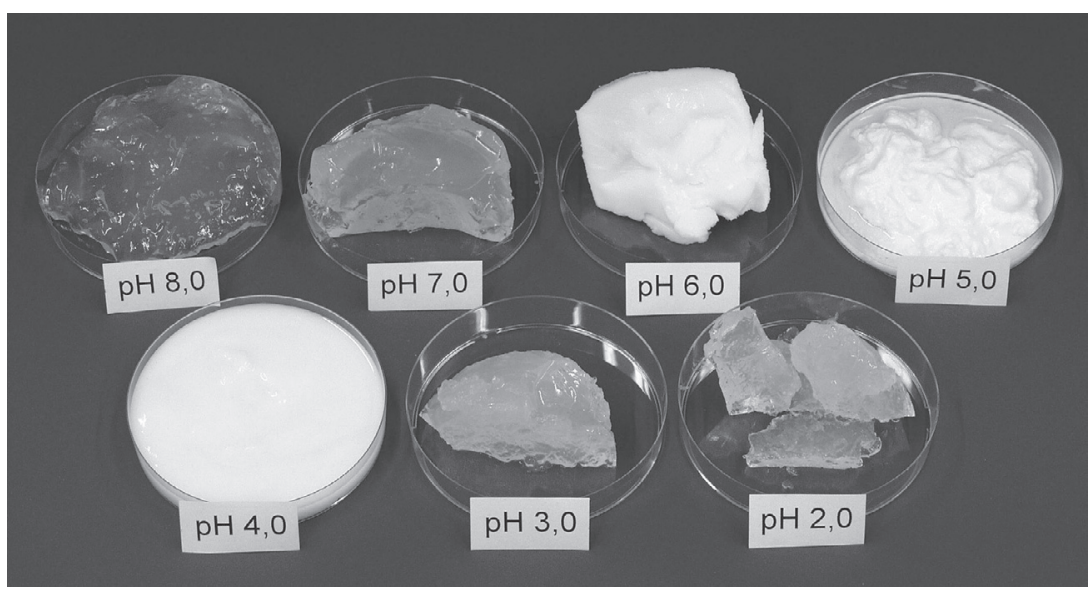

Figure 6. Gelation properties of whey protein isolate, dependent on the $\mathrm{pH}$ value (protein content = $11.25 \%$; heating conditions $=75^{\circ} \mathrm{C}, 45 \mathrm{~min}$ ).

proteins ( $\mathrm{pH} 4-5)$ the gelation properties are negligible. A low number of intermolecular bonds and a small net charge are insufficient for gelation. At $\mathrm{pH}$ values of $2-3$, the net charge of the proteins is positive, and the sulphydryl groups demonstrate a high stability. This means that covalent disulfide bridges cannot be formed and the gelation occurs mainly via hydrophobic bonds. A high net charge leads to translucent gels from regular thin strings of protein aggregates $[10,14,34,36]$. Table I reflects that WPC achieves the highest gel strength at $\mathrm{pH} 8$, while WPI does this at $\mathrm{pH}$ 6. Comparable results were found during repeated trials with several batches of the whey protein products. Tang et al. [37] also found that WPI gels exhibited maximum gel stiffness at about $\mathrm{pH}$ 5.5. Burgess and Kelly [5] found that the gel strength of WPI decreases 
with increasing $\mathrm{pH}$ from 7 to 9 . Renard and Lefebvre [32] demonstrated that the critical protein concentration for gelation of $\beta$-lactoglobulin is lowest at $\mathrm{pH} 5-6$. It is suggested from these results that there may be an interrelationship with the concentration of $\beta$-lactoglobulin in the whey protein products. However, some papers describe a steady rise in the gelation properties of whey proteins with increasing $\mathrm{pH}[12,24$, 27]. This cannot be confirmed by the studies on hand. Differences in functionality between WPC and WPI can be expected because of the differences in composition and the production processes performed. In addition, the treatment with acids and caustic solutions during the ion-exchange chromatographic process in the manufacture of the protein isolate may also have an influence on the tertiary structure of the proteins, and thus on the resulting functional properties.

The gelation properties of whey proteins are also dependent on the ionic environment, especially from the relation of monovalent and divalent cations [36]. Table II revealed that the relation of $\mathrm{Ca} / \mathrm{Na}$ is about two-to-one with the concentrate and around one-to-four with the isolate. The studies of Veith and Reynolds [39] have shown that high-strength gels from WPC can be produced by acidic processing to remove divalent cations, and subsequent neutralization with sodium hydroxide. The present investigations show that an increase in the gel strength due to a higher salt content is only recognizable with WPI. A considerable increase in the gel firmness of WPI by addition of sodium chloride was also determined by Caussin et al. [6]. It is known that addition of $\mathrm{NaCl}$ or $\mathrm{CaCl}_{2}$ to dialyzed solutions of WPC or WPI results in an increase in gel strength until maximum values are reached, and then the gel strength decreases at higher salt concentration. However, there is some disagreement on the optimum concentration of salts required to achieve maximum gel strength, because this is primarily related to the composition and to the effects of the processing history of the products $[12,36]$. An increase in the ionic strength (Tab. I) by addition of sodium chloride leads to a reduced repulsion of the unfolded protein molecules, and thus increases both the aggregation capacity and the intramolecular repulsion, which contributes to an additional stabilization of the threedimensional network $[9,10,14]$. However, the high ionic strength in general and the high calcium content in particular of WPC may be preventing the formation of strong gels in the system used. Calcium was shown to increase the aggregation rate, but above a certain optimum concentration, coagulation occurred as a result of excessive protein-protein interactions [36, 37].

For the characterization of rheological properties, whey protein gels were produced in the measuring device of the rheometer, applying the same time-temperature conditions of heating as with the penetration measurements.

Figure 7 reveals that the gels made from WPI are significantly stronger than those made from WPC. This result is in agreement with the penetration measurements. The storage modulus ( $\left.\mathrm{G}^{\prime}\right)$ is eight- to tenfold higher, the loss modulus (G") about five- to sevenfold. This result is in contrast to the studies of Tang et al. [37] and Puyol et al. [30], who found higher $G^{\prime}$-values for commercial WPC than for WPI samples. The loss angle of WPI is lower than that of WPC. This makes it clear that gels with WPI are more elastic than WPC gels. The storage modulus of WPI and the storage and loss moduli of WPC increased with increasing frequency, while the loss modulus of WPI revealed no clear dependence on the frequency, resulting in a stronger decrease in the loss angle of WPI with increasing frequency.

\section{CONCLUSION}

It can be concluded from the studies on hand that the gelation properties of WPI are superior to those of WPC. It could be shown that the strength of heat-induced gels prepared with WPI is higher than with WPC. Furthermore, WPI gels are more elastic than gels of WPC. The superior gelation properties of WPI are mainly due to the different composition of the main components; especially to the higher content of $\beta$-lactoglobulin. However, the low content of 

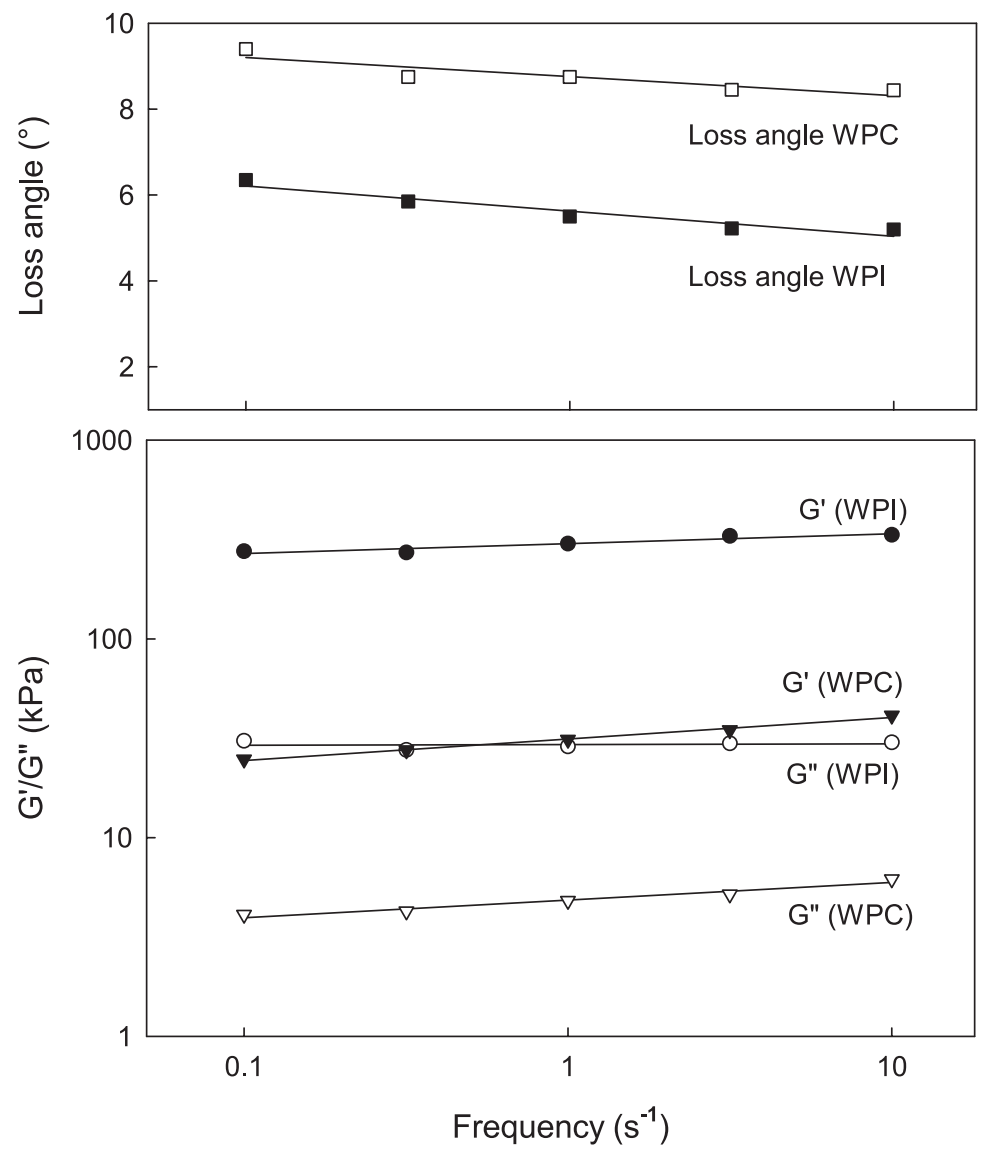

Figure 7. Rheological properties of gels prepared from WPC and WPI.

glycomacropeptide, non-protein-nitrogen and proteose peptone in WPI may also be important for the formation of strong gels. WPI seems more sensible to an increase in the ionic strength, resulting in stronger gels than with WPC. The highly different appearance and consistency of WPI gels in relation to the $\mathrm{pH}$ offers multiple options for the application of WPI in food processing.

Acknowledgement: We gratefully acknowledge the technical assistance of Beate Hiller, Sabine Splitzer, Inge Spreckels and Ernst Johannsen.

\section{REFERENCES}

[1] Alting A.C., Hamer R.J., de Kruif C.G. Paques M., Visschers R.W., Number of thiol groups rather than the size of the aggregates determines the hardness of cold set whey protein gels, Food Hydrocolloids 17 (2003) 469479 .

[2] Anonymous, ANNEX IV of EU regulation (EG) $625 / 78$, Storekeeping of skim milk powder, 1981.

[3] Brandenburg A.H., Morr C.V., Weller C.L., Gelation of commercial whey protein concentrates: effect of removal of low-molecular-weight components, J. Food Sci. 57 (1992) 427-432. 
[4] Bryant C.M., McClements D.J., Molecular basis of protein functionality with special consideration of cold-set gels derived from heat denatured whey, Trends Food Sci. Technol. 9 (1998) 132-151.

[5] Burgess K.J., Kelly J., Technical note: selected functional properties of a whey protein isolate, J. Food Technol. 14 (1979) 325-329.

[6] Caussin F., Famelart M.-H., Maubois J.-L., Mineral modulation of thermal aggregation and gelation of whey proteins: from $\beta$-lactoglobulin model system to whey protein isolate, Lait 83 (2003) 1-12.

[7] Cayot P., Lorient D., Structure-function relationships of whey proteins, in: Damodaran S., Paraf A. (Eds.), Food proteins and their applications, Marcel Dekker, Inc., New York, USA, 1997, pp. 199-223.

[8] Cheftel J.C., Cuq J.L., Lorient D., Lebensmittelproteine, Behr's-Verlag, Hamburg, Germany, 1992.

[9] Clark A.H., Kavanagh G.M., Ross-Murphy S.B., Globular protein gelation - theory and experiment, Food Hydrocolloids 15 (2001) 383-400.

[10] De La Fuente M.A., Singh H., Hemar Y., Recent advances in the characterisation of heat-induced aggregates and intermediates of whey proteins, Trends Food Sci. Technol. 13 (2002) 262-274.

[11] De Witt J.N., Klarenbeek G., Adamse M., Evaluation of functional properties of whey protein concentrates and whey protein isolates. 2. Effects of processing history and composition, Neth. Milk Dairy J. 40 (1986) 4156.

[12] De Witt J.N., Hontelez-Backx E., Adamse M., Evaluation of whey protein concentrates and whey protein isolates. 3 . Functional properties in aqueous solution, Neth. Milk Dairy J. 42 (1988) 155-172.

[13] Dickinson E., Hydrocolloids at interfaces and the influence on the properties of dispersed systems, Food Hydrocolloids 17 (2003) 25-39.

[14] Doi E., Gels and gelling of globular proteins, Trends Food Sci. Technol. 4 (1993) 1-5.

[15] Elgar D.F., Norris C.S., Ayers J.S., Pritchard M., Otter D.E., Palmano K.P., Simultaneous separation and quantitation of the major bovine whey proteins including proteose peptone and caseinmacropeptide by reversed-phase high-performance liquid chromatography on polystyrene-divinylbenzene, J. Chromatogr. A 878 (2000) 183-196.

[16] Farrel Jr. H.M., Qi P.X., Brown E.M., Cooke P.H., Tunick M.H., Wickham E.D., Unruh
J.J., Molten globule structures in milk proteins: implications for potential new structure-function relationships, J. Dairy Sci. 85 (2002) 459-471.

[17] Foegeding E.A., Davis J.P., Doucet D., McGuffey M.K., Advances in modifying and understanding whey protein functionality, Trends Food Sci. Technol. 13 (2002) 151159.

[18] Fox P.F., Milk proteins: General and historical aspects, in: Fox P.F., McSweeney P.L.H. (Eds.), Advanced Dairy Chemistry, Vol. 1, Part B, 3rd edn, Kluwer Academic/ Plenum Publishers, New York, 2003, pp. 1-48.

[19] Haque Z.U., Influence of milk peptides in determining the functionality of milk proteins: a review, J. Dairy Sci. 76 (1993) 311320.

[20] Holt C., McPhail D., Nevison I., Nylander T., Otte J., Ipsen R.H., Bauer R., Ögendal L., Olieman K., De Kruif K.G., Leonil J., Molle D., Henry G., Maubois J.L., Perez M.D., Pujol P., Calvo M., Bury S.M., Kontopidis G., McNae I., Sawyer L., Ragona L., Zetta L., Molinari H., Klarenbeek B., Jonkman M.J., Moulin J., Chatterton D., Apparent chemical composition of nine commercial or semicommercial whey protein concentrates, isolates and fractions, Int. J. Food Sci. Technol. 34 (1999) 543-556.

[21] Holt C., McPhail D., Nylander T., Otte J., Ipsen R.H., Bauer R., Ögendal L., Olieman K., De Kruif K.G., Leonil J., Molle D., Henry G., Maubois J.L., Perez M.D., Pujol P., Calvo M., Bury S.M., Kontopidis G., McNae I., Sawyer L., Ragona L., Zetta L., Molinari H., Klarenbeek B., Jonkman M.J., Moulin J., Chatterton D., Some physico-chemical properties of nine commercial or semi-commercial whey protein concentrates, isolates and fractions, Int. J. Food Sci. Technol. 34 (1999) 587-601.

[22] Huffman L.M., The importance of whey protein fractions for WPC and WPI functionality, in: Proceedings of the second international whey conference, 27-29 Oct 1997, Chicago, Int. Dairy Fed. Special Issue 9804, 1998, pp. 197-205.

[23] Karman A.H., van Boeckel M.A.J.S., Evaluation of the Kjeldahl factor for conversion of the nitrogen content of milk and milk products to protein content, Neth. Milk Dairy J. 40 (1986) 315-336.

[24] Kinsella J.E., Whitehead D.M., Proteins in whey: chemical, physical, and functional properties, in: Kinsella J.E. (Ed.), Advances in food and nutrition research, Vol. 33, Academic Press Inc., San Diego, 1989, pp. 343-438. 
[25] Meisel H., Frister H., Chemical characterization of a CPP isolated from in vivo digests of a casein diet, Biol. Chem. Hoppe-Seyler 389 (1988) 1275-1279.

[26] Messens W., Van Camp J., Huyghebaert A., The use of high pressure to modify the functionality of food proteins, Trends Food Sci. Technol. 8 (1997) 107-112.

[27] Morr C.V., Foegeding E.A., Composition and functionality of commercial whey and milk protein-concentrates and isolates - a status-report, Food Technol. 44 (1990) 100111.

[28] Nakano T., Ozimek L., Determination of sialic acid by the thiobarbituric acid reaction in sweet whey and its fractions, J. Agric. Food Chem. 47 (1999) 2613-2616.

[29] Otte J., Ju Z.Y., Skriver A., Qvist K.B., Effects of limited proteolysis on the microstructure of heat-induced whey protein gels at varying pH, J. Dairy Sci. 79 (1996) 782-790.

[30] Puyol P., Perez M.D., Calvo M., rheological properties of commercial whey protein samples from the MADGELAS survey, Int J. Food Sci. Technol. 34 (1999) 565-572.

[31] Qi P.X., Brown E.M., Farrell Jr. H.M., 'New views' on structure-function relationships in milk proteins, Trends Food Sci. Technol. 12 (2001) 339-346.

[32] Renard D., Lefebvre J., Gelation of globular proteins: effect of $\mathrm{pH}$ and ionic strength on the critical concentration for gel formation. A simple model and its application to $\beta$-lactoglobulin heat induced gelation, Int. J. Macromol. 14 (1992) 287-291.

[33] Resch J.J., Daubert C.R., Rheological and physicochemical properties of derivatized whey protein concentrate powders, Int. J. Food Prop. 5 (2002) 419-434.

[34] Resch J.J., Daubert C.R., Foegeding E.A., $\beta$-lactoglobulin gelation and modification: effect of selected acidulants and heating conditions, J. Food Sci. 70 (2005) 79-86.

[35] Sharma M., Haque Z.U., Wilson W.W., Association tendency of beta-lactoglobulin $\mathrm{AB}$ purified by gel permeation chromatography as determined by dynamic light scattering unter quiescent conditions, Food Hydrocolloids 10 (1996) 323-328.

[36] Singh H., Havea P., Thermal denaturation, aggregation and gelation of whey, in: Fox P.F., McSweeney P.L.H. (Eds.), Advanced Dairy Chemistry, Vol. 1, Part B, 3rd edn, Kluwer Academic/ Plenum Publishers, New York, 2003, pp. 261-1282.

[37] Tang Q.T., McCarthy O.J., Munro P.A., Oscillatory Rheological comparison of the gelling characteristics of egg white, whey protein concentrates, whey protein isolate, and $\beta$-lactoglobulin, J. Agric. Food Chem. 42 (1994) 2126-2130.

[38] Vardhanabhuti B., Foegeding E.A., McGuffey M.K., Daubert C.R., Swaisgood H.E., Gelation properties of dispersions containing polymerized and native whey protein isolate, Food Hydrocolloids 15 (2001) 165-175.

[39] Veith P.D., Reynolds E.C., Production of a high gel strength whey protein concentrate from cheese whey, J. Dairy Sci. 87 (2004) 831-840.

[40] Wang T., Lucey J.A., Use of multi-angle laser light scattering and size-exclusion chromatography to characterize the molecular weight and types of aggregates present in commercial whey protein products, J. Dairy Sci. 86 (2003) 3090-3101.

[41] Williams P.A., Phillips G.O., Introduction to food hydrocolloids, in: Phillips G.O., Williams P.A. (Eds.), Handbook of hydrocolloids, Woodhead Publishing Limited, UK, 2000, pp. 1-20. 